\title{
The Soviet modernisation of the public road landscape
}

\author{
Kristine Vugule ${ }^{1}$, Simon Bell ${ }^{2}$ \\ ${ }^{1}$ Latvia University of Life Sciences and Technologies, Department of Landscape Architecture and \\ Planning, Jelgava, Latvia \\ ${ }^{2}$ Estonian University of Life Sciences, Chair of Landscape Architecture, Tartu, Estonia
}

\begin{abstract}
Under the Soviet regime and as part of the development of the economy, the Latvian road infrastructure and its associated landscape went through major changes. Through modernisation old roads were straightened, historically established road routes and their surroundings changed, new roads planned and constructed, some elements of the road landscape disappeared and new ones emerged. Snow and wind protection hedges were planted along open stretches. With the increase of public transport many unique bus stop pavilions rest areas for drivers and tourists were constructed. A lot of attention was paid to roadside views and aesthetics through the use of tree plantings. The aim of this study was to explore the heritage of road planning and landscape development in Latvia during the Soviet era from 1945 to 1991. The study used literature review and analyses of maps and archival materials from the Latvian road museum supported by fieldwork. Elements which are disappearing as the road network is upgraded through European structural funding were identified through map analyses of different time periods and a number of field studies of sample stretches of roads, were undertaken. The road infrastructure and the landscape of that time is part of the cultural heritage of the $20^{\text {th }}$ century and is connected to the development of the rural economy and collectivisation and to military preparedness. The study uncovered a well-developed road planning and landscape design theory which was applied in Latvia and used as an example in other Soviet Republics.
\end{abstract}

\section{Introduction}

The Soviet totalitarian regime, through massive collectivisation and development of kolkhozes destroyed the traditional way of life in the Latvian countryside and influenced the further development of the Latvian landscape. In 1961, the Communist Party of the Soviet Union set a goal to eliminate the major differences between city and countryside. In order to make life in the Latvian countryside more similar to other countries of the USSR, traditional Latvian estates were proclaimed as remnants of the past, people were moved into villages, farmsteads were demolished, the fields were meliorated and

\footnotetext{
${ }^{1}$ Corresponding author: kristine.vugule@llu.Iv
} 
turned into kolkhoz fields ${ }^{2}$. The way the traditional landscape changed and how agricultural landscape patterns transformed under the Soviet system are described in several studies $[2,3,4,5]$.

Due to the development of the overall economy, the Latvian road infrastructure and its associated landscape also went through major changes. During the Soviet era most attention was paid to reconstruction and repair of the existing road network. Road elements were fixed according to road categories set by USSR standards. New roads were also constructed. A lot of attention was paid to road safety. Safety issues were solved through careful planning of road alignments through the terrain. Roadside landscaping was used to increase traffic safety. A Latvian road engineer, Peteris Dzenis and an architect, Velta Reinfelde were the first to develop road landscape design theory, which was applied in Latvia during the Soviet era. Several complex road reconstruction projects which included landscape design were carried out on the road sections RigaJurmala, Riga-Pskov and Plavinas -Madona [6]. Some issues of Soviet era road landscape development in Latvia have been addressed in previous studies by the authors $[7,8]$.

The aim of this study was to explore the heritage of road planning, development of road design ideas and the spatial effects of road and landscape planning in Latvia during the Soviet era from 1945 to 1991 . The study was based on a literature review and analyses of maps and archival materials from the Latvian road museum supported by fieldwork. Elements which are currently disappearing as the road network is upgraded through European structural funding were identified through map analyses of different time periods and a number of field studies of sample stretches of roads, were undertaken between 2015 and 2018.

\section{History of road administration and traffic network development}

With the strict centralization of power, all issues of the USSR were decided in Moscow. All economic sectors in Latvia were subject to central planning and had to work according to five-year plans. Ministries had the leading role and controlled about $80 \%$ of industrial production in Latvia [1].

A large proportion of the road system had been destroyed during the Second World War. About $1000 \mathrm{~km}$ of crushed stone-surfaced roads and some 660 bridges were destroyed. Repair work to these roads started in the 1950s. The busiest roads leading to and from Riga were reconstructed first. In the post-war years, roads in Latvia according to their significance were divided into categories: firstly, the All-Union major roads, which were managed by the High Commission of the People's Commissariat of the Highways (Ušdor), founded by Moscow, and secondly roads of republic-level significance, which were under the authority of the Council of Ministers of the Main Roads. In some cities, there were districts under both administrations. The third category comprised local roads connecting smaller cities, villages and kolkhoz centres.

1952, when the Latvian Main Road administration established a design group comprising three people, can be considered to be the beginning of organized and specialised road design. In four years the team grew to 12 people. The Road Administration of the Ministry of Transport and Roads of the Latvian SSR established

\footnotetext{
${ }^{2}$ See entries "Padomju totalitārisms Latvijā" [Soviet totalitarianism in Latvia]; "Kolhozi" [Kolhoz] "Lauksaimniecības kolektivizācija" [Collective agriculture] in [1]. Retrieved from, respectively: https://www.letonika.Iv/groups/default.aspx?cid=31707;

https://www.letonika.Iv/groups/default.aspx?title=Kolhozi/32469;

https://www.letonika.Iv/groups/default.aspx?cid=31694 [available on 10 April 2018].
} 
the Republican Road Design Group in 1955. The rapid development of roads began in 1956, when the two road administrations were merged. Initially, 21, and later 26 road operation districts were created. 11 road construction districts were gradually established for larger construction works. In order to take care of the roadside vegetation, road operation districts had a vegetation or landscape manager [9]. Several road administrations also had their own plant nurseries for road landscaping needs.

Significantly important for the development of Latvian roads was the inclusion of local roads in the national road network in October 1963. The sixties were a time of large road reconstruction works. Roads were reconstructed according to their significance in five categories according to USSR standards (Table 1) [9].

Table 1: The standards of road construction applied in Latvia (Source: [9])

\begin{tabular}{|c|c|c|c|c|c|}
\hline \multirow{2}{*}{$\begin{array}{c}\text { Number of } \\
\text { automobiles }\end{array}$} & I cat. & II cat. & III cat. & IV cat. & V cat. \\
\cline { 2 - 6 } & $\mathbf{6 0 0 0}$ & $\mathbf{3 0 0 0 - 6 0 0 0}$ & $\mathbf{1 0 0 0 - 3 0 0 0}$ & $\mathbf{2 0 0 - 1 0 0 0}$ & $\mathbf{2 0 0}$ \\
\hline Calculates speed km/h & 120 & 100 & 80 & 70 & 60 \\
\hline Road width & 23 & 12 & 12 & 10 & 10 \\
\hline Number of lanes & 4 & 2 & 2 & 2 & 2 \\
\hline Width of lanes & 3.5 & 3.5 & 3.5 & 3.0 & 3.0 \\
\hline Width of shoulder & 2.5 & 2.5 & 2.5 & 2.0 & 2.0 \\
\hline Minimal radius of curve & 600 & 400 & 250 & 125 & 60 \\
\hline
\end{tabular}

After 1957, 23 asphalt factories were built. In the 1970s and 1980s, 29 production bases, 2484 apartments and 145 individual houses as well as sports and recreation facilities for road workers were also built. All projects for these structures were developed by the road design institute founded in the 1950's [10].

A road design organisation "Latdorautoprojets" was established on the basis of the road design group in 1958 and later, in 1965, the Latvian SSR State Road and Transport Design institute "Celuprojekts" was formed. Starting from 1962 the principles of spatial planning of roads became widely applied in practice. Road landscaping work also started at this time. The architect Velta Reinfelde started to work in road design in 1959 and in cooperation with Peteris Dzenis a book about road design and landscaping was published. The book was also translated into Polish. Road landscaping work reached its maximum impact in the middle of the 1970s and started to decline after Velta Reinfelde retired.

There was a rule until 1978 that road axes should not deviate from the existing one by more than $25 \%$ during capital reconstruction work. Latvian road planners often did not follow this. Under the supervision of chief engineer Edgars Vikmanis, who set the technical policy, Latvian designers developed their own style to design within maximal parameters, generous curve radii, minimal rise and fall, maximal visibility and in cases of road reconstruction tried to get permission for reconstruction into a higher category road. These differences in approach were visible in practice, where some of road sections were obviously built according to design projects from neighbouring republics. Latvian road designers worked with a view to the future, for example when the road from Riga to Ogre needed reconstruction in 1962, the designers proposed it to be a first category road with four lanes. Officials from the central administration of the republic could consider this to be excessive and reflecting a negative impact from the West. Later, however, when the $30,7 \mathrm{~km}$ long section of the road was completed, it was clear that other places in Latvia also needed first category roads [9]. 
Complex road and landscape design projects were prepared by the Latvian Road and Transport Design institute and carried out during road reconstruction [11]. Latvian road designers and engineers were proud of several successful projects. In 1972 the resort road with six lanes was built from Riga to Jūrmala. It had the latest infrastructure of the time - car dividing barriers across the road, nocturnal lighting, traffic signs giving variable guidance on the permitted speed or on the risk of fog or ice on the road. Above all six lanes flyovers were built without intermediate support and on both sides of the road were petrol stations. People called this road "six minutes west".

In 1977, a $27,7 \mathrm{~km}$ long four-lanes section of the Vidzeme motorway from Riga to Sēnite was finished together with the most modern traffic junction in the Baltic states at that time. A large roundabout or traffic island, six light-weight overpasses, one $162 \mathrm{~m}$ long pedestrian walkway, four car parks, pedestrian walkways and two $89 \mathrm{~m}$ and $75 \mathrm{~m}$ long respectively pedestrian tunnels made this junction convenient and easy to understand. For the first time in post-war practice, a plate bearing the names of the project designers and construction managers was placed on the tunnel wall. The project of a particular section from Garkalne to Sēnite was original in concept and paid special attention to forest protection. One of traffic lanes was routed along the forest firebreak leaving a $130 \mathrm{~m}$ wide section of forest between the carriageways. Most traffic junctions on first category roads were built in a form of clover leaf with large radii. In the 1960s and later ring roads were constructed around many cities [9].

Comparing available historic maps, one can see that the road network during the Soviet era did not change dramatically. Many roads were slightly straightened during reconstruction work, new connections were built to link up larger cities and ring roads around many cities were designed.

\section{Road infrastructure and landscape design}

During the road reconstruction which started after the Second World War, significant attention was paid to road aesthetics. More than 14 million roubles were spent on roadside planting alone [6]. In 1945 vegetation was established at first along $200 \mathrm{~km}$, in later years $104 \mathrm{~km}$, then $190 \mathrm{~km}$ and 220 to $280 \mathrm{~km}$ each year until 1953 , when the numbers reduced to $170 \mathrm{~km}$ per year. Fewer trees were planted along All-Union major roads. Alleys were still planted along many roads. The armed forces had strategic motives, trees being planted close to roads in order to hide them from above. Trees were mostly behind the roadside ditches.

Until 1960 roadside planting was mainly considered as roadside decoration. Later tree group planting became more common. Peteris Dzenis wrote in the magazine "Latvian Auto and Road Worker" that greenery was used in the USSR the same way as abroad in order to indicate the direction of a road, to increase traffic safety in conditions of poor visibility and at night [12].

During the Soviet era, in the 1960s-1970s, Velta Reinfelde and Peteris Dzenis developed a road landscape design theory. It consisted of route placement in the landscape and organization of tree and vegetation planting. Straight sections of the road were not planned to be longer than $2-3 \mathrm{~km}$, while road safety depended very much on the routing. One of reasons for exceeding the speed limit was an attempt to pass through the boring sections as quickly as possible. It was already emphasised at that time that it was important not to let meadows and fields to overgrow. Landscape should not be filled with too many details; new elements should be placed next to existing ones. Attention was paid to seasonality. If new tree groups were planned as landmarks, they 
should also include deciduous trees [13]. The theory is described in their book which was published in Russian and translated into other languages.

Road planning and landscaping work was planned in four main directions. First was the placement of roads in the landscape and the design of the aesthetic landscape. Second was traffic safety improvements by controlling the visibility and using planting in a way that helped to avoid accidents, prevents road snowdrifts, protect agricultural land from car exhaust fumes and reduce traffic noise. Third was improvement of rest areas, parking places and bus stops along the road. The final direction was nature protection and care about runoff water [6].

A pilot project following the landscape design theory was partially implemented along the Plavinas -Madona road, where tree groups and shrubs were planted outside the road protection zone. The reconstruction project for the Riga- Pskov road landscape was carried out with reference to the Plavinas Madona pilot example. There were plans to prepare such projects for all highways which needed reconstruction [9].

Eleksis et al described the main principles used in decorative planting planning in 1967, stressing that plantings should enhance safety, should not make the landscape dull, while it could cause driver fatigue and optical illusions. Decorative plantings should stress the direction of movement, mark curves, signal approaching built-up areas and other objects. Scenic groups of trees were considered the most appropriate for the Latvian landscape. Alleys should be planted only in cities and along roads leading to important buildings. Tree groups were planned according to local conditions, not closer than $5 \mathrm{~m}$ from the road, tree spacing 2 to $8 \mathrm{~m}$ from each other. For visual orientation, dense groups of trees were placed on the outer edge of a curve. Trees with lighter leaves were planted on hill tops and with smaller and darker leaved trees in the valleys in order to stress the topography [13]. Along straight sections with traffic in both directions 5 to $20 \mathrm{~m}$ long groups of decorative shrubs were planted in the road dividing zone in order to protect drivers from being dazzled by headlights. In flat areas vegetation was planned as new elements, but in hilly areas as a supplement to the existing landscape [14].

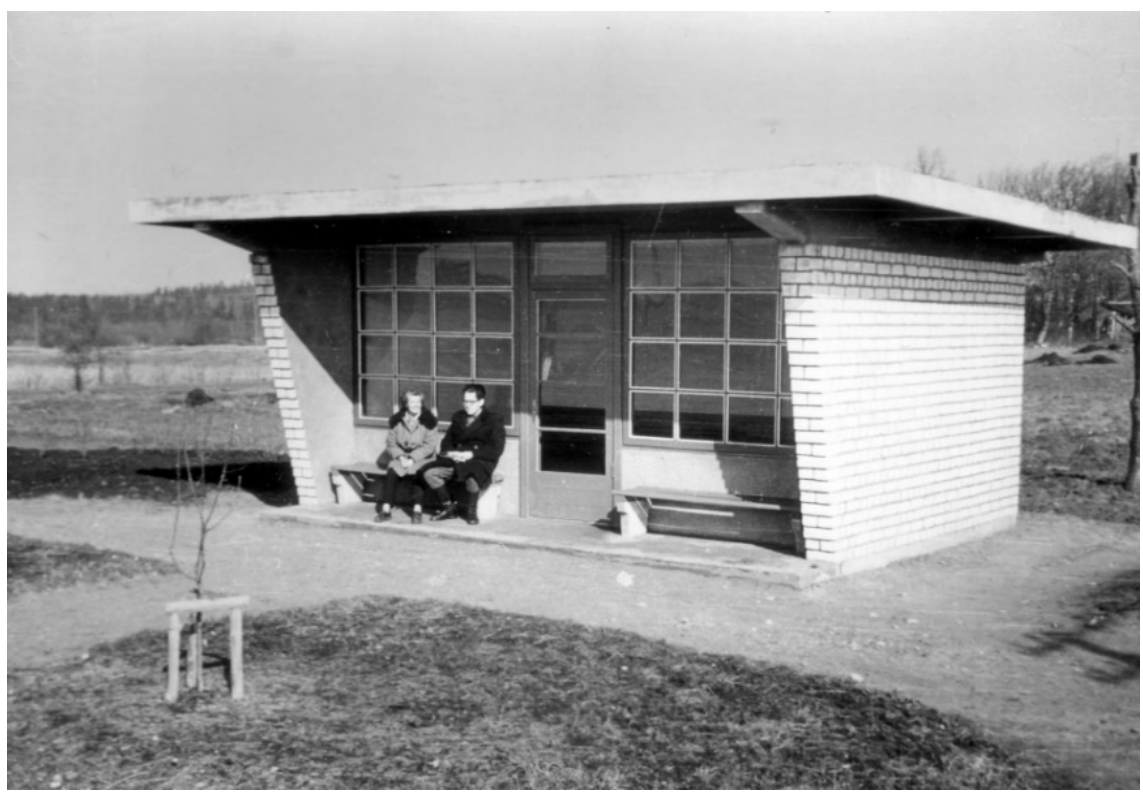

Figure 1: Bus shelter type "Б-1", 1960s, architect Velta Reinfelde and engineer Gunārs Binde from the institute "Cel,uprojekts" are sitting on the bench [Source: Latvian road museum]. 
Bus connections and routes were some of the most densely developed in the whole Soviet Union. More than 1500 bus routes operated in 1988, there were 1300 bus pavilions with decorative plantings, 300 parking places and 90 rest areas. Bus stops were located 2 to $4 \mathrm{~km}$ apart near cities and 500 to $100 \mathrm{~m}$ in the countryside [14].

Latvia was famous for its bus pavilion designs across the USSR. Catalogues with standard bus stop designs were published (Fig.1). Models of Latvian pavilions were demonstrated in exhibitions and were given awards.

Places for temporary parking when vehicles had broken down, short term and long term resting areas for passengers and tourists were also designed. Rest areas were sited in attractive places and, depending on usage, were equipped with facilities. Special attention was paid to the size, configuration and architectural design of rest areas [13]. Roads were provided with a targeted information system, comfortable bus stops with shelters, intersections, green plantings and designed recreation and parking spaces.

In the reconstruction of roads, a large tree replanting technique was successfully applied in the winter months. During the Riga-Bauska road reconstruction in 1969, groups of large trees were replanted, moved from former railway plantations [15].

\section{Remaining elements of Soviet-era road landscape}

The changed structure of the traditional countryside management can be clearly seen from roads. Large fields, canalised small rivers, apartment houses in the middle of the rural landscape and various kolkhoz buildings are still present in many places in the Latvian countryside. Farm buildings are often reconstructed or demolished, but plenty of abandoned and ruined ones are still present in the landscape (Fig.2).

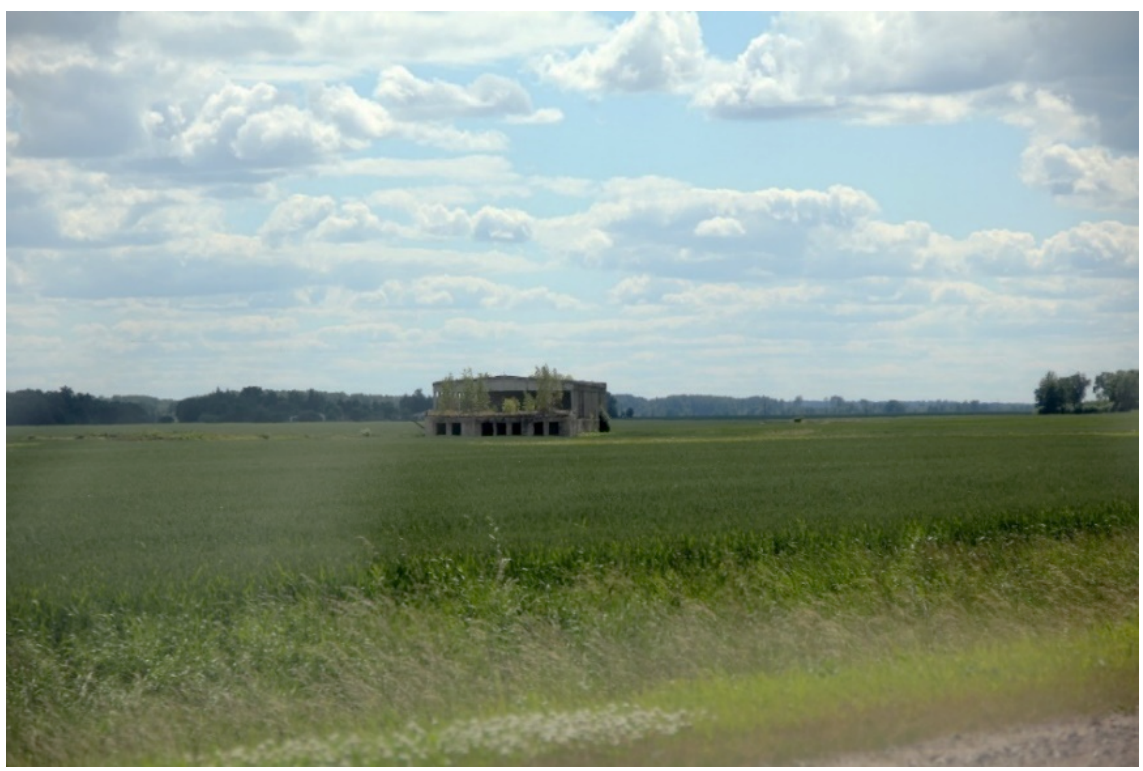

Figure 2. Remains of farm buildings on the road Jelgava -Tērvete [Photo: Vugule, 2015].

Different campaigns were organized in the Soviet era. One of these was under the slogan "Let's turn the roads into blooming gardens". As a result, approximately 126000 apple, cherry and other fruit trees were planted along roadsides in the 1960s. There 
was a precise accounting of the number planted trees in each road district. Fruit trees comprised one fifth of the all trees planted [9]. Remnants of these plantings are still present along many roads (Fig.3).

Other elements which have remained from the Soviet era in some places are spruce tree hedges which were planted to protect the road from drifting snow in winter. The origins of these hedges are the railway protection hedges dating from the $19^{\text {th }}$ century. Later the technique was taken to road protection and complex snow protection systems, consisting of several rows of trees and shrubs were designed. Today these hedges are mostly overgrown and block the view to countryside. In some places they are trimmed, but usually the plants are in not very good conditions (Fig.4).

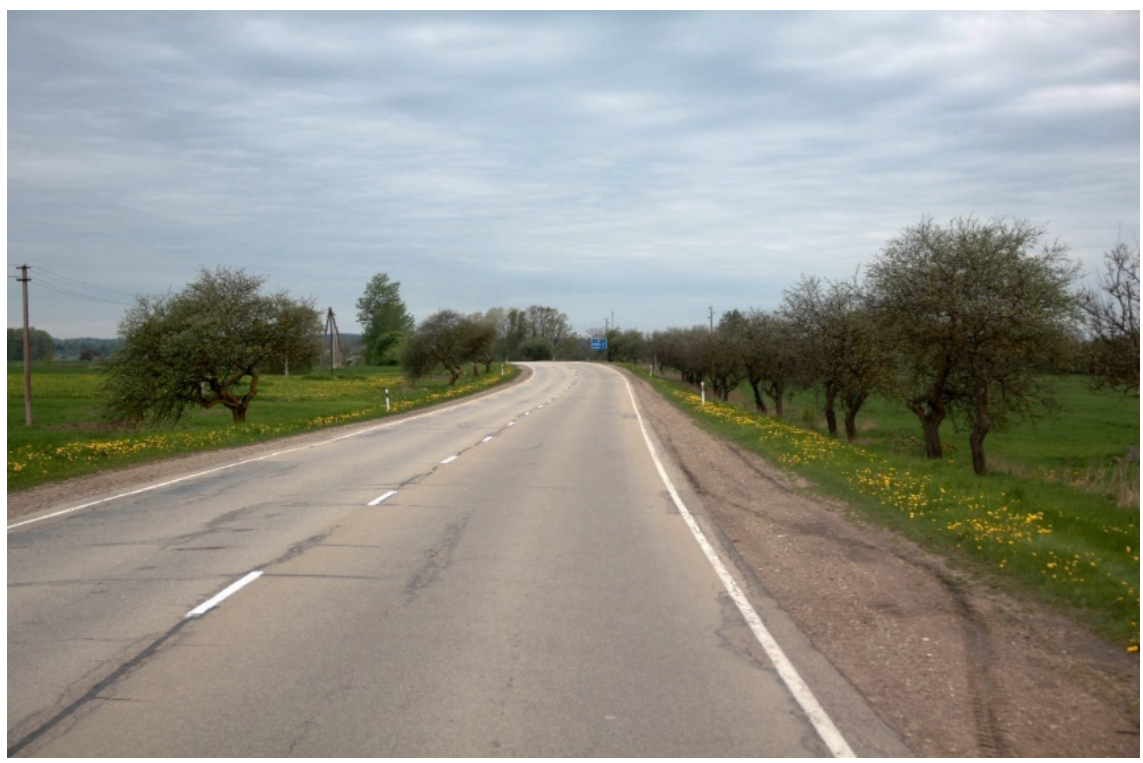

Fig.3. Apple trees along the road Rīga-Liepāja [Photo: Vugule,2015].

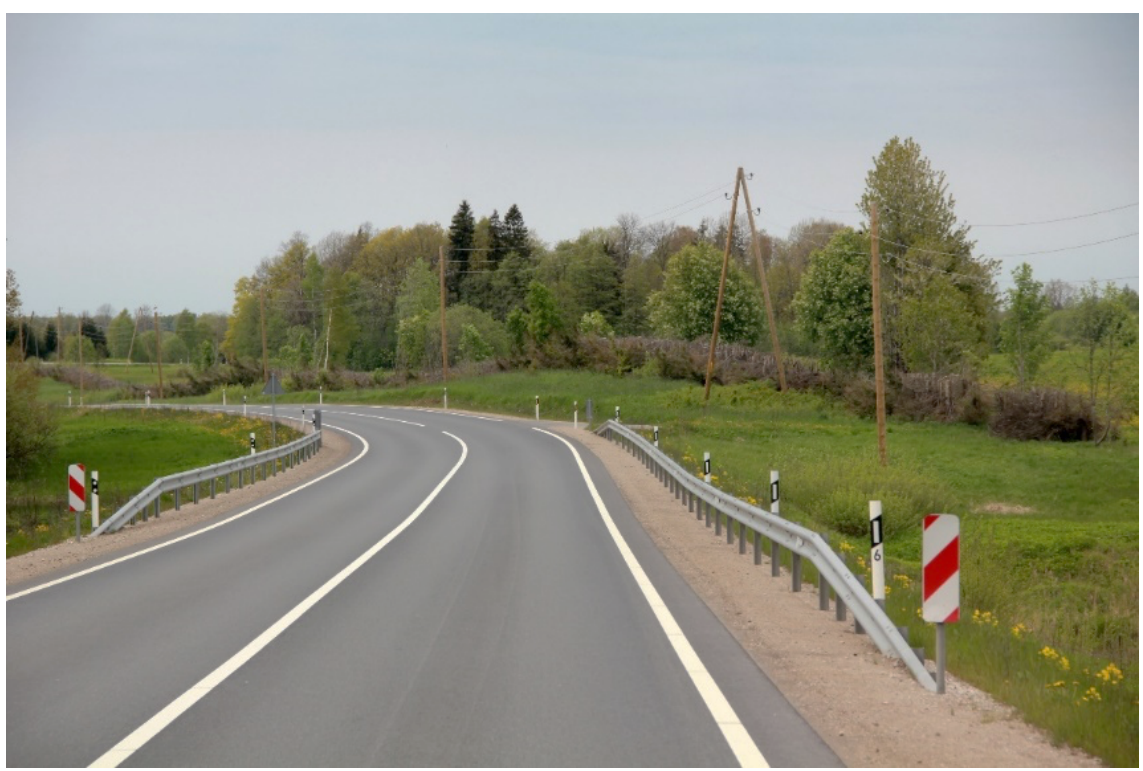

Fig.4. Snow protection hedges from spruce trees along the road Rĩga-Liepāja

[Photo: Vugule,2015]. 
There were development directives and plans from the higher administration to all Soviet republics which were not necessarily suitable for each country. Many negative impacts in different fields can be witnessed from those days, but in the road sector and road landscape design many positive developments took place. It was easier to plan the road landscape from the point of view of land ownership. As it all belonged to the state, larger changes could be made if necessary. Road and landscape design theories were developed but at the same time articles from magazines show the impact of their application depended very much on local road operation districts and the people who took care about specific roads.

\section{Short resumes}

Kristine Vugule, Bachelor of Environmental science, qualification of landscape architect and Master's degree in architecture obtained at Latvia University of Agriculture. At present lecturer and researcher at the Faculty of Environment and Civil Engineering, department of Landscape Architecture and Planning of the Latvia University of Life Sciences and Technologies, works on $\mathrm{PhD}$ thesis about "Road landscapes, their values and development scenarios".

Simon Bell, PhD chair professor of landscape architecture at the Estonian University of Life Sciences, Associate Director of the OPEN space Research Centre at the University of Edinburgh and visiting professor at the Faculty of Environment and Civil Engineering, department of Landscape Architecture and Planning of the Latvia University of Life Sciences and Technologies since 2012.

\section{References}

1. Latvijas vēstures enciklopēdija - Tildes Datorenciklopēdija Latvijas Vēsture [Tilde's Online Encyclopedia of Latvian History] (1998-2012). LETONIKA.LV. Retrieved from: https://www.letonika.Iv/groups/default.aspx?g=1\&r=2 [available on 10 April 2018].

2. BELL, S.; NIKODEMUS, O.; PENEZZE, Z. et al. 2009. "Management of cultural landscapes: what does this mean in the Former Soviet Union: A case study from Latvia", Landscape Research, vol. 34, n 4: 425-455.

DOI: https://doi.org/10.1080/01426390903020328

3. BELL, S.; PENEZE, Z.; NIKODEMUS, O. et al. 2004. "The value of Latvian rural landscape", in Z. Roca, T. Spek, T. Terkenli et al., European Landscapes and Lifestyles: The Mediterranean and beyond, Lisbon, Edições Universitárias Lusófonas: 347-362.

4. NIKODEMUS, O.; BELL, S.; GRINE, I. et al. 2005. "Impact of economic, social and political factors on the landscape structure of the Vidzeme Uplands in Latvia", Landscape and Urban Planning, vol. 70, $\mathrm{n}^{\circ}$ 1-2: 57-67.

DOI: https://doi.org/10.1016/j.landurbplan.2003.10.005

5. MELLUMA, A. 1994. "Metamorphoses of Latvian landscapes during fifty years of Soviet rule", GeoJournal, vol. 33, n 1: 55-62.

DOI: https://doi.org/10.1007/bf00810136

6. Latvijas ceḷu zalāa rota [The Green Decoration of Latvian Roads] (1988). Riga, Valsts ražošanas apvienība Latvijas autoceḷi. 
7. VUGULE, K.; BELL, S.; STOKMANE I. 2004. "Road landscape development in Latvia up to the $21^{\text {st }}$ century", Scientific Journal of Latvia University of Agriculture Landscape Architecture and Art, $\mathrm{n}^{\circ}$ 4: 10-16. Retrieved from: http://llufb.Ilu.Iv/Raksti/Landscape_Architecture_Art/2014/Latvia-UnivAgriculture_Landscape_Architecture_Art_VOL4_2014_10-16.pdf [available on 14 March 2019].

8. VUGULE, K. 2013. "The Latvian landscape as seen from the road", in Annual $19^{\text {th }}$ International Scientific Conference Proceedings. Research for Rural Development 2013, vol. 2, Jelgava, Latvia University of Agriculture: 120-127. Retrieved from: http://llufb.llu.Iv/conference/Research-for-Rural-

Development/2013/LatviaResearchRuralDevel19th_volume2-120-127.pdf [available on 14 March 2019].

9. ANDREJSONS, V.; SVIK̦IS, H. 2016. Latvijas zemes ceḷi un autoceḷi 1940-1988 [Latvian Gravel and Autoroads 1940-1988], Riga, Latvijas Valsts ceḷi - Latvian State Roads.

10. Celu nozares vesture [History of the road sector] (2015?). [Online]. Latvijas Valsts ceḷi - Latvian State Roads. Retrieved from: https://lvceli.lv/muzejs-unekskursijas/celu-nozares-vesture/ [available on 10 April 2018].

11. SLËDE, E.; VIKMANIS, E. 1980. Latvijas PSR autocelu būves pieredze [Experience of Latvian SSR road construction], Riga, Avots.

12. DZENIS, P. 1960. "s.n.", Latvijas Auto un Celu Darbinieks [Latvian Auto and Road Worker], $\mathrm{n}^{\circ} 32$.

13. ELEKSIS, K.; SVIĶIS, H.; VIKMANIS, E. 1967. Automobilu ceḷ remonts un uzturēšana [Repair and Management of Automobiles], Riga, Liesma.

14. DZENIS, P; REINFELDE, V. 1968. Пространнственное проектйрование автомобильных дорог [Spatial Planning of Automobile Roads] Moscow, Транспорт [Transport].

15. TAUBENBERGS F. 1972. "Autoceḷu apstādījumi šodien un rīt" [Planting Along Roads Today and Tomorrow], Latvijas Autotransports un Ceḷi, n²: 15-19. 